\title{
Language Contact and Linguistic Change in the Chaco
}

Lyle Campbell ${ }^{1}$

\section{Introduction}

The goals of this paper are to examine several aspects of language contact involving languages of the Chaco region. More specifically, I discuss changes that are unexpected in situations of intensive contact; I consider possible explanations for resistance to lexical borrowing; I address the implications of language contact in these Chaco languages for claims about change in language contact situations in general; I evaluate claims regarding mixed languages in the region; and I investigate diffused linguistic traits in the Chaco and determine whether the Chaco is a linguistic area.

\section{Language contact in Misión La Paz}

Several aspects of what I report here are based on findings from research involving multilingualism in Misión La Paz, Salta Province, Argentina (henceforth MLP). Three indigenous languages are spoken in MLP in addition to Spanish: Chorote, Nivaclé (also called Chulupí, sometimes Ashluslay), and Wichí (formerly called Mataco). All three are members of the Matacoan language family (called familia mataco-mataguaya in Spanish), but they are not particularly similar to one another, diversified on the order of Germanic languages.

Misión La Paz is located just across the Pilcomayo River from Paraguay and about 20 kilometers from Bolivia. At the time the fieldwork research there began (2001) there were about 650 inhabitants, but it has since grown to over 850. The indigenous people there live in very poor socioeconomic conditions, and they maintain much of the traditional culture.

There are c.2,500 speakers of Chorote, and c. 8800 speakers of Nivaclé (called Chulupí in Argentina, sometimes Ashluslay in various spellings), with c.400 in Argentina and c.8400 in Paraguay. Wichí is the largest language of the

1 University of Hawai'i Mānoa. 
area, with an estimated number of speakers ranging from c.25,000 to c.34,000, all in Argentina except the small Noctén group in Bolivia. Younger people and most men in MLP also speak Spanish. (Campbell and Grondona 2012a.)

\subsection{Language choice in Misión La Paz}

Some background on aspects of the multilingualism in MLP is needed to comprehend the changes to be described below and their implications. Speakers and hearers in conversations are typically not speaking the same language to one another. People communicate regularly with speakers of different languages, but very often not in the same language as the one addressed to them. Each participant in a conversation typically speaks his or her own language, but other participants in the conversation reply in their own language. This non-reciprocal use of different languages in conversation is called dual-lingualism (Lincoln 1979). Linguistic exogamy is also common in MLP, where each spouse speaks his/her own language and is addressed in and understands the other spouse's language in return - a spouse does not accommodate by speaking the other spouse's language. Each maintains and uses his or her own language. Linguistic exogamy is the norm for Chorote and Nivaclé speakers, and for most Wichí who grew up in MLP, but not necessarily for other Wichí who have moved to MLP later. (See Campbell and Grondona 2010 for details.)

In general, people identify with a single language and speak it with all others. They claim to understand but not speak one and in many cases both of the other two indigenous languages. Nevertheless, the other two indigenous languages are spoken around them constantly and they usually have perfect comprehension of the languages that they claim not to speak. The choice of language with which individuals identify does not correlate with any of the social variables that might be suspected, not with the gender of the child, the gender of the parent whose language is chosen, prestige, power, residence, etc. In numerous interviews and in a demographic survey of the whole town, when people were asked on what basis they decided to choose one language over the others to identify with, the answers typically reflected personal feelings or aesthetics, typically along the lines of "it just felt better," "I liked it more," "it seemed more comfortable," and "I thought is was nicer." The result is that siblings in the same family often speak different languages from one another, and most households (typically made up of an extended family of three generations) have multilingual interactions all the time. No one language has greater value or prestige than the others. They are considered absolutely equal and the question of whether one might be considered more prestigious or powerful or better in some way strikes inhabitants of MLP as strange in the extreme, basically beyond comprehension. 
It may be asked whether dual-lingualism here is recent, the result to the bringing together of speakers of different languages with the founding of MLP in 1944. Perhaps it is in part. However, there are indications that the patterns of multilingualism seen in MLP today also precede its founding. There are few historical accounts that mention these languages. Neither Chorote nor Nivaclé are identified clearly in colonial sources, but rather they were commonly considered part of the Mataguayo and Mataco (Wichí) groups (see Kersten 1904). The Chorote were first mentioned by Lozano (1733[1941]:59, 218) as "Choroties"; the group he called "Xolota" (Lozano 1733[1941]:82) were probably also Chorote. However, next to nothing was known of either Chorote or Nivaclé until the late 1800s. The "Ashluslay" (the Chorote name for the Nivaclé) were first mentioned in the report of the Daniel Campos expedition of 1883 (Métraux 1946:236), by Cardús (1886, cited in Pelleschi 1897), and by anthropologists who visited them in the early years of 1900 (von Rosen 1904, Herrmann 1908, Nordenskiöld 1912). Nevertheless, there are mentions in the limited literature that suggest that dual-lingualism is not new among the Chorote and Nivaclé of the Pilcomayo region. For example, Padre Doroteo Giannecchini reported:

From Pikirenda to another 30 (?) leagues more or less, continuing to the Paraguay [River] they take the name Chulupies: and all the right bank of the Pilcomayo from our Mission of Noctenes [Wichíes of Tartija, Bolivia] to the Paraguay it is the same tribe, with words and customs somewhat different; but in substance, it is the same language, and among them they understand one another perfectly each one speaking his jargon. (Emphasis added, cited in Lafone Quevedo 1895:344, 1897:53.) ${ }^{2}$

See also Lafone Quevedo (1897:53), Nordenskiöld (1912:23, 26), Siffredi (1973:73), De Wavrin (1926:42), Karsten (1932:19), and Sušnik (1986-1987:33) for similar reports. (Note that the Nivaclé are called Chulupí in Argentina and formerly were also often called Ashluslay.) We can conclude from these reports that most probably these groups were already practicing dual-lingualism at least to some extent from the time of the their earliest mention.

\subsection{Consequences of language contact in MLP}

It has often been observed in situations of intensive language contact that languages tend to undergo structural changes which make them more similar

2 De Pikirenda hasta otras (?) leguas más o menos, por adelante hasta el Paraguay toman el nombre Chulupies: y toda la ribera derecha del Pilcomayo desde nuestra 1a Misión de Noctenes hasta el Paraguay, es la misma tribu, con palabras, y costumbres algo diferentes; pero en la sustancia, es la misma lengua, y entre sí se entienden perfectamente hablando cada uno su jerigonza. 
to one another. For example, in famous cases from India, different languages in contact have changed to become more structurally similar to one another, so that rather exactly matching morpheme-by-morpheme translations become possible (see Gumperz and Wilson 1971, Nadkarni 1975). Many scholars expect this sort of structural convergence from languages in intensive contact. This raises the question: do the three indigenous languages in MLP show evidence of similar change towards convergence? The answer is "no," although the topic deserves more detailed investigation.

First, these languages, as well as some others in the Chaco region, resist lexical borrowings (see below). They have accepted very few loanwords from Spanish or from other languages, and instead they use native linguistic resources to create new words to accommodate concepts acquired through contact (acculturation). For example, the word for 'goat' is not a loan from Spanish as in so many other indigenous languages of Latin America, but rather, for example, Nivaclé tašinštax 'goat' is derived from tašinša 'grey brocket deer (Mazama gouazoubira)' + -tax 'similar to', and Chorote sonta 'goat' is from sona? 'grey brocket deer' + - $t a$ 'similar to' (Campbell and Grondona 2012a, see below). That is, speakers of these languages acquired the concept, but accommodated the acculturation by using native resources in their languages, avoiding lexical loans. Second, contrary to expectations, these languages, though in constant daily contact with one another, appear to be diverging structurally in some traits, not converging as expected. The following examples illustrate this. (Incidentally, the examples given below also show that these languages, though related genetically, are not especially similar to one another, as mentioned above.)

All three languages have $/ \mathrm{t} /$, voiceless ' $\mathrm{l}$ ' phonemically, as in Chorote top/lop, Nivaclé tup, and Wichí tup 'nest', to cite one set of cognate forms. However, younger Chorote speakers in MLP are now changing this. They no longer have $/ \mathrm{t} /$; rather they have changed it to a consonant cluster of $/ \mathrm{h} /$ or $/ \mathrm{x} /$ + voiced /l/, which alternates with just plain $/ \mathrm{l} /$ (with no $/ \mathrm{h} /$ or $/ \mathrm{x} /$ ) in some contexts, especially word-initially and word-finally, as in:

$\begin{array}{ll}\text { xlop / lop } & \text { 'nest' } \\ \text { xla?a / la?a } & \text { 'fruit' } \\ \text { xlam / lam } & \text { 'he' } \\ \text { xloma / loma } & \text { 'day' } \\ \text { axlu } & \text { 'iguana' } \\ \text { samehl / samel } & \text { 'we' } \\ \text { amehl / amel } & \text { 'you (pl.)' }\end{array}$

This change has taken place in spite of the fact that these Chorote speakers are in constant intensive contact with the other two languages that preserve 
their unitary voiceless "l", /1/. This goes against areal linguistic expectations about languages in such close, intensive contact. It is expected that if the other languages in the intensive contact situation have voiceless "l" there would be pressure on Chorote not to change its voiceless "l" but instead to remain structurally similar to the other two languages in this trait.

In another example, both Nivaclé and Wichí have contrastive first-person plural inclusive and exclusive pronominal forms, as seen in the contrasts in Nivaclé between the a. and b. pairs in (1), (2), and (3).

(1) a. kas-wa?tša

We.INCL-PRO.ROOT

'we' (all of us)

b. yi-wa?tša-?eł

1ST.PERS.EXCL-PRO.ROOT-PL

'we' (but not you)

(2) a. katsi-tata

our.INCL-father

'our father' (of all of us)

b. yi-tata-Peł

1ST.PERS.EXCL-father-PL

'our father' (but not yours)

(3) a. šta-sekkis

we.INCL-scrape

'we scrape it' (all of us)

b. xa-sekkis-eł

1sT.PERS.excl-scrape-PL

'we scrape it' (but not you)

The inclusive-exclusive contrast in Wichí is seen in (4) through (6).

(4) a. n-Pameł

We.INCL-PRO.ROOT

'we' (all of us)

b. no-łamel, o-łamel

We.EXCL-PRO.ROOT

'we' (but not you)

(5) a. ła-čoti

our. INCL-grandmother

'our grandmother' (of us all) 
b. n-čoti

our.EXCL-grandmother

'our grandmother' (but not yours)

(6) a. ya?-lan

we.ACT.INCL-kill

'we kill it' (all of us)

b. na-lan

we.ACT.EXCL-kill

'we kill it' (but not you) (Wichí examples from Terraza 2008).

However, Chorote speakers in MLP have lost this inclusive-exclusive contrast in first person plural pronouns and now have only a non-contrastive first-person plural. The single Chorote form in (7a) and (8a) is compared with the Nivacle contrasting forms in (9b)-(9c) and (10b)-(10c). (The noun and verb roots are cognates in these languages.)

(7) a. si-Pleh

'our language'

b. kas-kli?š

'our language' (INCL)

c. xa-kli?š-eł

'our language' (EXCL)

(8) a. a-lan-a

we-kill-sur

'we killed it'

b. šta-klan

'we kill it' (INCL)

c. xa-klan-eł

'we kill it' (EXCL)

Here again, we would not expect Chorote to lose a morphological contrast that is so salient in the other two languages which speakers of Chorote hear and understand constantly in MLP.

The third example involves change in Nivaclé. In both Chorote and downriver Paraguayan dialects of Nivaclé, when active verbs appear with the 'prospective' (future intent) clitic, they are required to take the pronominal prefixes for stative verbs - even when it is an inherently active verb that is involved - as seen in the contrasts in Chorote between (9a) and (9b) and between (10a) and (10b). 
(9) a. a-Pwešiy

1ACT-hunt

'I hunt and gather'

b. si-?wešiy=ayi

1STATIVE-hunt=PROSP

'I'm going to hunt and gather'

(10) a. hi-kapehnan

2ACT-cook

'you cook'

b. in-kapehnan=ayi

2STATIVE-cook $=[$ PROSP $]$

'you are going to cook'

In this construction, the stative prefix required with the 'prospective' clitic is the original state of affairs for these languages. However, MLP Nivaclé has undergone an innovation. The corresponding construction in Nivaclé takes not stative personal-pronoun prefixes, but can only bear the active ones, as in (11a). It is ungrammatical with the stative subject prefix, as seen in (11b).
a. $\mathbf{x a}-$ wo? $=\mathbf{x a y u}$
1ACT-hunt.for $=$ PROSP
'I'm going to hunt for it'
b. *tsi-woP=xayu
1STATIVE-hunt.for=PROSP

We would expect the requirement in Chorote and other Nivaclé dialects (several speakers of which also live in MLP) for stative pronominal prefixes on the verb in these constructions to have influenced MLP Nivaclé to maintain the construction with the stative pronominal affixes. However, this is not what happened. (For discussion and other examples, see Campbell and Grondona 2010).

These examples make clear that the assumed pressure towards conformity and convergence among the three languages in intensive language contact did not have much effect; rather, that these languages are undergoing changes that result in greater difference among the three rather than greater convergence, while changes towards convergence are not evident.

\section{Lexical borrowing}

Several Chaco languages are remarkable for the general lack of loanwords from Spanish, unlike many other Latin American Indian languages, and for 
their use of native linguistic resources to accommodate concepts acquired through contact with outsiders. I illustrate this primarily with examples from Nivaclé and Chorote (Matacoan languages) (see Campbell and Grondona 2012a for details). Nivaclé and Chorote generally do not allow items of acculturation to introduce foreign lexical material to these languages, but rather they utilize their own linguistic resources to create terms for newly acquired items (see below).

There are hispanisms (loanwords from Spanish) in Nivaclé and Chorote, but extremely few. A few examples follow:

[1] 'ball, soccer'

Nvc pelota

Chr pelota

$<$ Spanish pelota 'ball'

[2] 'bus, truck'

Nvc mákina

Chr makina 'car, truck; engine-powered vehicle'

< Spanish máquina 'machine, car'

[3] 'cart'

Nvc kaletax

Chr kaleta 'cart (not 'car')'

< Spanish carreta 'cart'

[4] 'cow'

Nvc waka, Chr wakye

< Spanish vaca 'cow'

[5] 'horse'

Nvc kuwayu

(cf. Chr allenta, 'horse' [< allenah 'tapir' + -ta 'similar.to'])

$<$ Spanish caballo 'horse'

[6] 'job, work'

Nvc taleya < Spanish tarea 'task' (cf. ka-taleya-kl-et, 1PERs-task-PL-1PL';

literally 'our jobs')

(cf. Chr inkihmaye < 'in-kim-ye 'UnPOss-work-NOM')

[7] 'money, peso'

Nvc peso 'money, peso, pay, salary' < Spanish peso 'peso'

(cf. Chr Pot 'money, silver' < ?ot 'metal', also ?ot-t'ah 'bills' < $20 t$ 'metal' t'ah 'peel, bark, outer-layer'; and hiles 'change' literally 'small ones, its. children') 
[8] 'rice'

Nvc aros

Chr aros (also k'yemtaye 'rice', and ama?yehmuy 'rice' < 'rat excrement':

ama? 'rat' $y$-ehmu-y '3Poss-excrement-PL')

$<$ Spanish arroz 'rice'

[9] 'sugar'

Nvc asúka

Chr asóke (also tits'ohyin tamak 'sugar cane powder' < tits'ohyin 'sugar cane' (literally: 'one sucks it')' t-amak '3Poss-dust, powder')

< Spanish azúcar 'sugar'

[10] 'watermelon'

Nvc saniya < Spanish sandía 'watermelon'

(cf. Chr ilota)

It is far more common for terms for items of acculturation in these two languages to be created only from resources native to these languages. The following are some cases where borrowed Spanish words would be expected (see, for example, Brown 1999), based on equivalents in a large number of other indigenous Latin American languages (the typical Spanish source of the loans in other languages is given in parentheses after the English gloss).

[1] 'airplane' (avión):

Nvc yiфa?ya < yi-фa?ya '3 subJ-fly', literally: 'it flies'

Chr makina ihwilye 'flying machine' < makina 'vehicle, car, truck, machine', i-hwe?ye '3suBJ-fly'

[2] 'book' (libro):

Nvc watk'isxayanač uxxa?m < wat-k'-i?s-xayan-ač 'UNPOss-write-NOMPRODUCT.OF', ux-xa?m 'big-EMPH' (cf. 'paper' below)

Chr nohokinek 'book, notebook, paper', also noho:kinek wuhwam t'ohokis po? 'notebook that has many letters' < nohokinek 'notebook' wuh-wam 'big, many-INTENs' t'ohok-is 'letters' < t'ohok-is 'color, also now letter, drawing-PL', po?'it.has'

[3] 'bottle' (botella):

Nvc tnaxke ('water jug')

Chr inate

[4] 'bread' (pan):

Nvc woye, yukuwe

Chr woye ${ }^{7}$ 
[5] 'donkey' (burro):

Nvc kuwayu-tax < kuwayu-tax 'horse-SIMILAR.TO'

Chr malekye-tok < male:kye-tok 'mule-sIMILAR.TO"8

[6] 'church' (iglesia):

Nvc watišxanxa?wat < wat-išxan-xa-?wat 'UNPOSS-sing-NOM-PLACE.

WHERE' '

Chr inosekisawo literally 'house of advise' < inosek 'advise' isawo 'house'

[7] 'duck' (pato):

Nvc xokxayex 'duck'

Chr kayé? 'domestic duck', nyé?ni 'species of wild duck'

[8] 'flour' (harina):

Nvc klimši < klim-ši 'white-sufF'

Chr tamak 'powder, flour (<t-amak '3poss-dust'), also alina $<$ Spanish harina 'flour'

[9] 'frying pan, skillet' (sartén):

Nvc kaklatxanxa?wat < kaklat-xanxa-?wat 'fried-AGENT-PLACE.WHERE'

Chr kakye?etana?et literally 'place where one fries' < ka-kye?elhana-?wet 'PREF-fry-PLACE.WHERE'

[10] 'glass' (vidrio):

Chr intayeh lal tiwah(a)yi literally 'sight goes through it' < intayeh 'sight' lal 'it.goes/passes' tiwahyi 'to.the.other.side/through'

[11] 'goat' (chivo [also cabra, cabro]):

Nvc tašinštax < tašinša-tax ' grey.brocket.deer-SIMILAR.TO'

Chr sonta < sona1-ta 'grey.brocket.deer-SIMILAR.TO'

Chr ts'ahwan hitok nosohyi < ts'ahwan 'mock orange' hitok 'ugly' nosohyi 'sour'

[12] 'gringo, missionary' (gringo, misionero):

Nvc ele < loan from another language, no /1/ in Nivaclé. (Spanish misionero 'missionary' is starting to enter, in the speech of younger speakers.)

Chr sam Rehikye 'missionary', literally 'our relative' < sam '1PL

Independent Pronoun' ?ehekye 'our.relative', also inósekiwo? 'missionary, counselor' < inosek-iwo? 'advise-PERSON.wHo'; also tehtey ka?č'ityu 'gringo' < t-ehte-y '3Poss-hair-PL' ka?čityu 'yellow' 
[13] 'guitar' (guitarra):

Nvc kuwayu taka?s (literally 'horse's tail') < kuwayu 'horse' ta-ka?s

'3Poss-tail'

Chr a?lenta ikyes iwole? literally 'hair of horse's tail' (allenta 'horse', $i-$ kyes '3poss-tail', $i$-wole? '3poss-hair')

[14] 'jug, jar' (jarro):

Nvc takpe?y

Chr tetik 'jug, plate'

[15] 'knife' (cuchillo):

Nvc klesa

Nvc sahwe

[16] 'lemon' (limón):

Nvc niway< niway 'sour'

Chr nosohyi < nosohyi 'sour', also limon < Sp limón 'lemon'

[17] 'machete' (machete):

Nvc klesatax < klesa-tax 'knife-simiLAR.To'

Chr sahwetok < sahwe-tok 'knife-simiLAR.TO'

[18] 'mare' (yegua):

Nvc ta kuwayu ( $t a$ 'female article' kuwayu 'horse' < Sp caballo 'horse')

Chr allenta hilyihwu < allénta 'horse' hilyihwu 'female'

[19] 'match' (fósforo):

Nvc itatax < itax-tax 'fire-SIMILAR.TO'

Chr etye 'fire, match'

[20] 'motorcycle' (moto):

Nvc k'ututut (onomatopoetic)

Chr pohpoh (onomatopoetic)

[21] 'mule' (mula, macho):

Nvc maklika

Chr malekye

[22] 'needle' (aguja):

Nvc k'utxa?n 'thorn, needle'

Chr itán 'thorn, needle'

Note: the "needles" used for traditional weaving were long cactus thorns

from the 'cardón' (Cactaceae, Stetsonia coryne). 
[23] 'non-Indian person' (criollo):

Nvc samto

Chr kilayi

[24] 'onion' (cebolla):

Nvc šitxaklitax < šitxak 'wild onion (a wild onion-like plant)-SIMILAR.TO'

Chr sohwatahenpeh < sohwa-tah-hen-peh '?-SIMILAR.TO-EVID-EVID' (also sewoya $<$ Spanish cebolla 'onion')

[25] 'orange' (naranja):

Nvc asaktsitax < asaktsex-tax 'bola verde (kind of fruit)-sImILAR.TO'

Chr ts'ahwan hitok < ts'ahwan 'mock orange' hitok 'ugly'; also kats'ityuy

[26] 'ox, bull' (buey, toro):

Nvc wakatax < waka-tax 'cow-SIMILAR.TO'

Chr wakye layinye 'bull' < wakye 'cow' layinye 'male', also malekyetok 'ox' < malekye-tok 'mule-SIMILAR.TO'

[27] 'pencil' (lápiz):

Nvc watwank'isxawo <wat-wank(a)-ils-xa-wo 'UNPOSS-UNSPEC.OBJ-writeNOM-FOR'

Chr t'eta?ato:ye literally 'thing for writing' < t'--et-a?-toye "INDEF.SUBJwrite-PURPOSE'; and nohokinekikye 'thing for paper' < nohokinek 'paper', i-kye '3Poss-purpose' (also lapi < Spanish lápiz 'pencil')

[28] 'plate' (plato):

Nvc titeč (younger speakers use plato), yakutšiy 'plate' (older word, plato used more now) < yakut-šiy 'black-inside'

Chr tetik 'jug, plate', and tetik toihwom literally 'jug looking upwards' < tetik 'jug' toihwom 'it.is.placed.upwards'

[29] 'radio, tape recorder' (radio, grabador):

Nvc tišxan < t-išxan '3suBJ-sing'

Chr tikyenisyen literally 'it sings' < t-ikyénisyen 'INDEF.SuBj-sing' (now also radyo )

[30] 'school' (escuela):

Nvc watwank'eyxatsxanxa?wat < wat-wank(a)-k'eyxat-xanxa-?wat 'UNPOSS-UNSPECIFIED.OBJECT-send.message, advise-AGENT-PLACE.WHERE'. (Spanish escuela is used more now.)

Chr neysana?wet 'place of teaching' < n-eysan-?wet 'unPoss-teach- PLACE. WHERE'

(Spanish escuela is now used more in both languages.) 
[31] 'scissors' (tijeras):

Nvc klesa tka?klay < klesa 'knife' t-kakla-y '3Poss-leg-PL'

Chr inkasohnates, literally 'knives' inkasohnat-es 'knife-PL'

[32] 'sheep' (oveja):

Nvc tsašay < $t$-sa? š- $a y$ ' 3 Poss-leaf, feather, fur, wool-sufF'

Chr sonta wole po? < sonta 'goat', wole 'wool', po? 'it.has'

[33] 'table' (mesa):

Nvc itsakkunxa?wat < itsakkun-xa-?wat 'to.always.eat-NOM-PLACE.WHERE'

Chr toyape?e literally 'one puts things on it' < t-oy 'INDEF.SUBJ-place.

on', ape?e 'over', also inyekyuna?wet 'place to eat' <in-yekyun-?wet

'UNPOSS-eat-PLACE.WHERE', ti?yekyuna?ape?e, literally 'one eats on this'

$<$ ti-yekyuna 'INDEF.suBJ-eat', ape?e 'over', and if the table is used as a

desk, t'etaha?hi?wet 'desk' literally 'place on which to write' < t'-et-a?-ha

'INDEF.SUBJ-write-SUFF' 'hi?wet 'place'. (The Spanish loan mesa < Spanish mesa 'table' is also used, especially by younger speakers in Chorote.)

[34] 'telephone' (teléfono):

Nvc watč'anxatšyei < wat-tč'an-xatšiye 'UNPOss-listen-NOM'

Chr kamtinyenawetiki 'place in which to talk' < kamtinyen-wet-iki 'to

talk-PLACE.WHERE-SUFF', also takamtinyen 'one who talks' < t-kamtinyen

'INDEF.SUBJ- talk'

[35] 'window' (ventana):

Nvc watowatxa?wat < wat-owat-xa-?wat 'UNPOSS-See-NOM-PLACE.WHERE'

Chr inkayitas literally 'small door' < inkay-tas 'door-small, offspring ( $t$-as 'its-son')', sawohip'ot literally 'cover of the house' < sawo 'house' hi-p'ot '3Poss-cover'

[36] 'wristwatch' (reloj):

Nvc pa?kla $<$ pa?kla 'bracelet'

Chr kilayhikye? < kilay 'sun' hikye? 'for'

\subsection{Mechanisms for creating new lexical items}

The resistance of Nivaclé and Chorote to borrowing foreign words is accommodated by the patterns for creating new lexical items in these languages. To derive new words these languages rely extensively on a derivational suffix meaning 'similar to', on compounding or lexical formation from former phrases, and in a few cases also on onomatopoeia.

A number of the examples of acculturation just presented illustrate the affix meaning 'similar to' for introducing new lexical items. In Nivaclé 
the suffix is -tax, as seen in tašinš-tax 'goat' (< tašinša 'grey brocket deer' + -tax 'similar to'). Other instances are seen in [5] 'donkey', [17] 'machete', [19]'match', [24] 'onion', [25] 'orange', [26] 'ox, bull', and [27] 'table'. There are literally hundreds of words formed by this suffix (see Seelwische 1990). Chorote employs two different suffixes with approximately this meaning of 'similar to', -tok (as in malekye-tok 'donkey, ox' < malekye 'mule' + -tok, and -ta (in sonta 'goat' < sona? 'grey brocket deer' + -ta), seen earlier also in 'horse': Chr allenta, < a?lenah 'tapir' + -ta.

Other new concepts are handled by metaphorical extension of the meaning of existing words. The two examples 'bicycle' and 'soldier' illustrate neologisms by metaphor:

bicycle: Nvc siwaklak < siwaklak 'spider'; Chr siwalak < siwalak 'spider'

soldier: Nvc tukus < tukus 'ant'; Chr tokis < tokis 'ant'.

Speakers report that 'bicycle' from 'spider' reflects the fact that the wheels of a bicycle look like spider webs. Some speakers say 'soldier' from 'ant' reflects the fact that soldiers walk in single file, as ants do. Other examples created by such metaphorical extensions include: [8] flour < dust; [16] lemon < sour; [22] 'needle' < 'thorn'; [32] sheep < (its) fur; [36] 'wristwatch' < 'bracelet', etc.

Compounding and the process of forming lexical items from phrases is the mechanism behind other new words, seen for example in: [10] 'glass' < 'sight goes through it'; [13] 'guitar' < 'horse's tail', 'hair of horse's tail'; [29] 'radio' < 'it sings'; [31] 'scissors' < 'knife's legs'; etc.

Cases of new words based on onomatopoeia are fewer, exemplified in [20] 'motorcycle' (Nvc k'ututut, Chr pohpoh).

\subsection{Explanation for resistance to lexical borrowing?}

Why have these languages borrowed so few words from Spanish and other languages? In part it may have to do with the limited contact with Spanish speakers until the last 60 years or so, less than that experienced by many other indigenous groups in Latin America. In part it may have to do with the fact that mechanisms for creating new words were well established before Spanish contact, where these languages easily derived new words for things they came into contact with by, for example, attaching the Nivaclé -tax and Chorote -tok and -ta suffixes meaning 'similar to' to native words to produce a new name for formerly unknown thing. For example, Nivaclé ału-tax'alligator', from ału 'iguana', and Chorote aheye-tok 'vampire bat' derived from aheye 'bat', with the Nivaclé cognates, šeya-tax 'vampire bat' from šeya 'bat'. Since speakers of these languages were not accustomed to borrowing lexical material and since they already had grammatical means available for deriving new words, when 
the need to accommodate items of acculturation from Spanish contact arose, speakers of these languages relied on these already existing devices for new word creation and on the internal linguistic resources of their languages to come up with new names for new items.

It might be speculated, additionally, that the relative absence of loanwords may have something to do with the dual-lingualism and patterns of language choice and use in MLP. Could lack of borrowing be due in part to the fact that because people understand the various languages but choose to speak only one of them? Borrowing is usually associated with multilingual speakers, bringing words from one of the languages they speak into another one as they speak it. Could it be that if they do not actually speak the other languages which they understand that there is little call to import foreign words? If they never utter aloud the word in another language, why would they use the foreign word while speaking their own language?

\section{Claims about mixed languages}

We frequently see the claim in writings about this region that several languages were really only dialects of a single language, or more commonly that they involved mixed languages. This latter opinion is held by several scholars, and seems to have historical antecedents based on a misinterpretation of the dual-lingualism practiced in the region.

Padre José Cardús (in 1886, cited by Pelleschi 1897:53) gave "Chunupis" as one of the names by which the "Matacos" (Wichí) were known (Chunupí referring to the Nivaclé, called Chulupí in Argentina, not to be confused with the Vilela, also called sometimes Chunupí). Padre Doroteo Giannecchini (cited by Lafone Quevedo 1897:53) reported that: "The Noctenes, the Matacos, the Vejoses, the Guiznaes, the Chulupies are a single nation; all speak a single language and all have the same customs" ${ }^{3}$ - all these are Wichí groups except Chulupí (i.e. Nivaclé). Lehmann-Nitsche (1936:119) cited the common view before his time that Mataco (Wichí) and Chorote were just codialectos 'codialects' and gives this as the reason for why Chorote was so poorly known, almost unreported at the time. Recall Giannecchini's claim that they were of the same tribe and that the language was the same, though "they understand one another perfectly each one speaking his jargon [jerigonza]" (cited above).

Observers appear to have misunderstood the dual-lingualism among these groups and took it to mean the different groups were speaking varieties of the same language to one another rather than engaging in bilingual interactions.

3 Los Noctenes, los Matacos, los Vejoses, los Guiznaes, los Chulupies, son una sola nacion, que hablan todos una sola lengua y todos tienen las mismas costumbres. (Lafone Quevedo 1897:53.) 
A number of scholars assumed that these are "mixed" languages, apparently a misinterpretation based on observations of communication among speakers of different languages. The notion of language mixture is a recurring theme in the literature on Chaco languages. Hunt (1915:238) is sometimes cited as an early influential supporter of the view:

they [the Mataco-Mataguayo] were the original occupants of the whole Chaco region ... the varying dialects have been formed by fugitives from the north and north-west, who by conquest or intermarriage have annexed both country and language.

Tovar (1951:401) followed suit:

neighboring languages have mixed, because it is known that these tribes absorb one another, in the clearest and most perceptible way by means of stealing the women and annihilating neighboring men; in these mixtures and absorptions not only words pass from one language to another, but forms, which justifies the claim that in a happy moment Lafone made, speaking of the 'chameleon' tendencies' of these Chaco languages [Lafone 1896:138]. (Emphasis added. $)^{4}$

Hunt and Tovar belong to a language mixture tradition that includes also Lafone Quevedo (1896:134, 1915:xiii), Palavecino (1928), Tovar (1951, 1981:20), Sušnik (1978:123-24), Klein (1993), Braunstein (1993, 1996, Braunstein and Miller 1999, Martín and Braunstein 1990-1991:10), and Rossi (2003:126).

Braunstein (1996:23, 28-9) asserted that "it cannot be dismissed that we should begin to study some Chaco languages as the product of mixture and diffusion more than as the results of the exclusive development by internal tendencies." ${ }^{5}$ Braunstein and Miller (1999:10-11) wrote:

there was little cohesion at the level of ethnicity involving the collectivity of tribes (each with its own dialect) speaking a common language. But interactions between bands belonging to different linguistic groups were quite common, and, once stabilized, the interethnic units formed of such alliances were the origin of mixed languages and cultures.

4 Se ha ido mezclando con la de lenguas vecinas, porque sabido es cómo estas tribus se absorban unas a otras, de la manera más clara y perceptible mediante el robo de las mujeres y aniquilación de los hombres vencidos; en esas mezclas y absorciones pasan de unas lenguas a otras no sólo palabras, sino formas, lo que justifica la afirmación que en un momento feliz hizo Lafone, al hablar de las 'tendencias camaleónicas' de estas lenguas chaqueñas [Lafone 1896:138]. (Tovar 1951:401.)

5 No es descartable que debamos empezar a estudiar algunas de las lenguas chaqueñas como producto de la mezcla y la difusión más que resultantes del exclusivo desarrollo de tendencias internas. 
For example, Braunstein (1996:28) believes there is evidence that the Maká and possibly the "Chulupí" (i.e. Nivaclé) are groups that originated through the process of ethnic mixture. Braunstein (1993:8, 1996:23) reported from historical research "situations of Mataco (Wichí) and Chulupí (Nivaclé) groups living together around the beginning of the century on the left bank of the Bermejo River," ${ }^{\prime}$ and he concluded from this that it showed "without any doubt, a degree of intelligibility." In fact, he sees such a process behind "the diverse origins of most of the languages spoken in the Chaco today" (Braunstein and Miller 1999:10).

It appears that the interpretations offered of these sources reflect a situation similar to that of MLP today where at least some intermarriage took place and where at least some people engaged in dual-lingualism, not language mixture.

Influence towards mixed language interpretations may have also come from a different direction. In his famous classification of South American languages, Loukotka (1968) also spoke in terms of "mixed languages," though in a very different way from those cited above. For Loukotka, if in a given language, nine or more words looked borrowed to him from his list of 45 words for which he sought equivalence in the various languages, he considered it a mixed language. Of course, Loukotka's judgements of borrowing were only impressionistic, and anyway, a sizeable number of loanwords was not what others mean by the notion of mixed language. In any event, Loukotka (1968:51, 55) considered Guachí and Payaguá as "mixed languages" in his "Guaicuru stock," and Enimaga (Lilei, Cochabot, Apqe-Sepqe) and Maka (Nimacá, Towothli, etc.) as "mixed languages" in his "Mataco stock."

\section{Is the Gran Chaco a linguistic area?}

The Gran Chaco is the extensive dry lowland plain of central South America, stretching some 647,500 sq km across northern Argentina, Paraguay, southeastern Bolivia, and southern Brazil. It is bordered on the west by the foothills of the Andés, on the east by the Paraná and Paraguay rivers, on the north by the Mato Grosso plateau, and in the south by the Río Salado (Braunstein 1996:19, Brauenstein and Miller 1999:1, Métraux 1942:197). The Chaco is also a culture area (Métraux 1942, Murdock 1951, Miller 1999), a geographical area characterized by cultural traits shared across ethnic boundaries. It is sometimes assumed that culture areas will coincide with linguistic areas (Sherzer 1976), though this is not always the case (see Campbell 1997:330-1). This raises the question examined here: Is the Chaco a linguistic area, as well as a culture area? A linguistic area is a geographical area in which, due to language contact and borrowing, languages of a region come to share certain

6 "situaciones de convivencia entre parcialidades matacas y chulupíes hacia principios de siglo en la margen izquierda del Bermejo." 
structural features. Other names sometimes used to refer to linguistic areas are Sprachbund, diffusion area, adstratum, and convergence area.

\subsection{Languages of the Chaco}

More than twenty languages from six language families are found in the Chaco region, listed here. Alternative names are given in parentheses; extinct languages are signaled by an asterisk after the language's name. (See Campbell 2012a for details on these languages.)

Guaicuruan (Waykuruan):

Southern Guaicuruan Argentina

$$
\begin{aligned}
& \text { Apibón* } \\
& \text { Pilagá } \\
& \text { Toba (Qom, Namqom) } \\
& \text { Mocoví }
\end{aligned}
$$

Kadiwéu (Kadiwéu [Caduveo, Mbayá, Ediu-Adig], Mbayá) Brazil

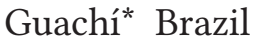

Payaguá* Paraguay

Both Guachí and Payagua are often thought to have Guaicuruan connections, though the evidence for this remains uncertain.

Matacoan (Mataco-Mataguayan)

Chorote (Chorotí, Manjuy) Argentina, Paraguay

(Dialects: Iyo'wujwa, Yohwaha, Manjuy)

Nivaclé (Niwaklé, Chulupí, Ashlushlay) Paraguay, Argentina

Maká (Macá, Enimaca, Enimaga) Paraguay

Wichí (Mataco, Mataguayo, Wenhayek) Argentina, Bolivia

(Dialect: Nocten, Güisnay [Pilcomayo Wichí], Vejos [Vejoz, Aiyo, Hueshuo])

Matacoan languages are diversified on a scale similar to Germanic languages. The Matacoan and Guaicuruan families have often been thought to be linked in a larger Macro-Guaicuruan "stock," but the evidence presented so far for this is not conclusive.

Mascoyan (Mascoian, Maskoyan, Lengua-Mascoy, Enlhet-Enenlhet) Paraguay Guaná (Cashquiha, Kaskihá, Enlhet) (not the Arawakan Guaná).

Sanapaná (Quiativis, Quilyacmoc, Lanapsua, Saapa, Sanam)

Angaité (Enenhlet)

Enlhet (Lengua) dialects or languages

Enlhet (Lengua Norte)

Enxet (Lengua Sur, Lengua, Vowak, Enhlit) 
Enenlhet (Mascoy, Mascoi, Machicui, Toba-Maskoy, Emok,

Toba-Emok, Toba of Paraguay, Quilyilhrayrom, Cabanatith, Tujetge )

These language names overlap and are not always distinguished consistently for these languages. (See Ethnologue.com for alternative treatments.)

Lule-Vilelan* Argentina

Lule*

Vilela $^{7}$

\section{Zamucoan}

Ayoreo (Ayoré, Moro, Zamuco, Pyeta, Yovai) Bolivia, Paraguay

(Dialect: Tsiricua, Tsiracua)

Chamacoco (Ishiro, Jeywo) Paraguay

(Dialects: Chamacoco Bravo [Tomaraho, Tomaraxa, Tumarahá], Ebitoso [Ebidoso, Ishiro])

Adelaar and Muysken (2004:623) includes extinct Guarañoca as Zamucoan, possibly an Ayoreo dialect.

Tupí-Guaranían (a branch of Tupían, see Rodrigues and Cabral 2012)

Some Tupí-Guaranían languages (of the Guaranían branch) are found in the Chaco or near enough for some scholars to associate them with the Chaco. These languages include:

Guaraní Antigo (Guaraní, old Guaraní) Brazil

Paraguayan Guaraní (Guaraní, Guarani Paraguayo, Avañee), Argentina, Brazil, Paraguay

Kaiwá (Kayowá, Kaiowá, Caiová, Caiguá, Pãi, Pãi-Tavyterã) Brazil, Paraguay

Nhandéva (Ñandeva, Chiripá) Argentina, Brazil, Paraguay

Chiriguano (Ava, Simba) Argentina, Bolívia, Paraguay

Isosó (Izozó, Izoceño, Chané) Bolívia, Paraguay

Tapiete Argentina, Boliva

Guayakí (Guayaquí, Aché, Axe) Paraguay

Guaráyoan Branch

Guarayo (Guarayú) Bolivia

Sirionó Bolivia

Yúki (Yuqui) Bolivia

7 There are perhaps two surviving semispeakers of Vilela, but no fully competent native speakers of the language remaining. 
Some other language families which have some representatives in the Chaco are Arawakan, Aymaran, Jêan, Quechuan, and Tupí-Guaranían (Tupían).

Charrúan* Uruguay, Argentina, Brazil

Charrúa*

Güenoa* (Minuane)

Chaná* Uruguay

There are a number of other extinct languages in the region that are poorly known, some with no linguistic attestation at all. Extinct and extremely poorly known languages of northwest Argentina are not included here (but see Campbell 2012a for details).

\subsection{Diffusion among Chaco languages}

Some observations of potentially diffused linguistic traits involving Chaco languages have been made from time to time, though a Chaco linguistic area has never officially been established (see Tovar 1961, Rona 1969-72, Kirtchuk 1996, Grondona 2003, Viegas Barros 2002:140, Adelaar and Muysken 2004:386, 499, Campbell and Grondona 2012b). Many of the shared traits that have been observed are of little value for defending a linguistic area, though some traits appear suggestive of a linguistic area in this region. I present first the traits with greatest promise of possibly supporting a linguistic area, followed by general discussion of the less promising traits.

\subsubsection{SVO Word order}

Shared basic word order has been cited as a trait of Chaco languages, though views as to what that order is have not all always been clear (see Tovar 1961:195, Tovar and Tovar 1984:202, Adelaar and Muysken 2004:499, Campbell 2012b). SVO basic word order is found in Matacoan and Guaicuruan languages, and Ayoreo (Zamucoan). Lule, however, has SOV (with NounAdjective, Modifier-Head). SVO basic word order may characterize many Chaco languages, but it does not set them clearly apart from languages of neighboring areas of South America.

\subsubsection{Gender}

Grammatical gender has been suggested as a Chaco areal trait (Tovar 1961, Aikhenvald 2000:80). Matacoan, Guaicuruan, Zamucoan, and Mascoyan languages have a masculine-feminine gender distinction. The contrast is not marked directly on the nouns but is manifested in the demonstratives which reflect the gender of the nouns they modify, as for example in Nivaclé: 
na p'eklenaxa [DEMONSTATIVE.visible.MASCULINE capybara] 'the capybara' ła swuklax [DEMONSTATIVE.visiblE.FEMININE anteater] 'anteater' na niwakle [DEMONSTATIVE.MASCULINE.VISIBLE man] 'the man' ła niwakče [DEMONSTATIVE.FEMININE.VISIBLE women] 'the women'.

Grammatical gender is a widely shared trait in the Chaco, though Chiriguano (Tupí-Guaranían) lacks a gender system (Dietrich 1986:92). However, gender as a grammatical category is also found widely elsewhere in South America (Campbell 2012b).

\subsubsection{Genitive classifiers. Matacoan}

Guaicuruan, Maskoyan, and Zamucoan languages have a genitive noun classifier (also called possessive classifier) construction for possessed domestic animals. In these languages it is not possible to say directly, for example, 'my cow'; rather, the 'possessive domestic animal classifier' is necessary, as in the following $(\mathrm{DEM}=$ Demonstrative, CLAS $=$ Classifier, $\mathrm{FEM}=$ Feminine, GEN $=$ Genitive, Poss $=$ Possessive):

Nivaclé (Matacoan)

Maká (Matacoan):

Mocoví (Guaicuruan):

Toba (Guaicuruan):

Pilagá (Guaicuruan)

Enlhet (Maskoyan): y-ikla? waka [my-GEN.CLAS cow] 'my cow'

yi-inek nunax 'my dog'

ñi i-lo pyoG '(the) my dog'

ha-na i-lo wa:ka [FEM-DEM 1POSS-GEN.CLAS cow] 'my cow', na a-lo pioq [FEM-DEM 2POSS-GEN.CLAS dog] 'your dog'

i-lo pyoq 'my (own) dog'

ši:mhïng šikk-tôščama [dog my-Domestic.Animal] 'my dog', tatáá nïn-tôščama [chicken ourDomestic.Animal] 'our chickens' (see Campbell 2012b).

Genitive classifiers are rare across the world's languages. Still, a number of other South American Indian languages also have genitive classifiers (Aikhenvald (2000:147), though usually as one member of a larger system that has several other noun classifiers as members. These Chaco languages differ in that they typically have only the genitive classifiers, not other kinds of noun classifiers, and this may distinguish them from languages of other areas. (For details, see Campbell 2012b.) 


\subsubsection{Rich set of demonstratives}

Chaco languages typically have a rich system of demonstratives, with forms distinguished on a number of different semantic parameters which include visible vs. not visible, as well as often also proximate, distal, extended horizontally, extended vertically, three-dimensional, known from first hand experience, known from hearsay, deceased, moving, and others.

\subsubsection{Active-stative verb alignment}

Active-stative alignment characterizes most of the Chaco languages and may be a legitimate area-defining feature (Grondona 2003, Adelaar and Muysken 2004:499). Matacoan and Guaicuruan languages are clearly activestative; Enlhet (Maskoyan) appears to be (Grubb 1914:319). Guaranían is well known for having active-stative alignment. This active-stative alignment is illustrated in Nivaclé (Matacoan), as in (12), where the verbs bear xa- ' 1 person active' (first person singular subject of an event, both transitive and intransitive), or they bear tsi- '1 person stative' (first person singular object of transitive verb or subject of stative intransitive verb):

(12) Active (agentive, event) Inactive (state, object)

\begin{tabular}{|c|c|c|c|}
\hline xa-фin & 'I kiss him/her' & tsi-фin & 'he/she kisses me' \\
\hline xa-xu? & 'I bite it' & tsi-xu?x & 'he/she bites me' \\
\hline xa-klan & 'I kill it' & tsi-klan & 'he/she kills me' \\
\hline xa-wa $\phi$ & 'I die' & tsi-čayu & 'I get used to, accustomed to' \\
\hline xa-?waklič & 'I walk' & tsi-ta?ya & 'I know' \\
\hline xa-kuma?x & 'I run' & tsi-tayč'e & 'I remember \\
\hline
\end{tabular}

In Mocoví (Guaicuruan) Intransitive verbs with active marking fall in the following groupings (Grondona 1998):

motion: ayo 'to fly', owo 'to walk', Re:t 'to escape to run away', ača:r 'to stand up', anat 'to

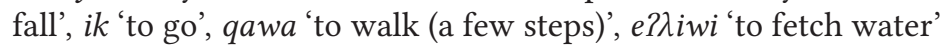

human/animate activity: ato 'sneeze', owir 'to arrive', a it 'to play', a?a 'to menstruate', ašil 'to get married', awog 'to copulate', epit 'to smile', ko?o 'to give birth', o?on 'to get married', o?wet 'to get dressed', onog 'to get naked, to undress', osog 'to get naked, to undress', qogon 'to urinate', ato 'to yawn',

inanimate activity: e?ya:m 'to boil'

Some examples of Mocoví intransitive active verbs are:

(13) $s$-a $\lambda$ it [1ACt play] 'I play'

(14) $s$-anatn)i [1ACT fall.down] 'I fall down' 
(15) $s$-qawa [1ACT walk] 'I walk'

(16) $s$-o ?wet [1 1 ACT get.dressed] 'I get dressed'

Intransitive verbs with stative marking fall into the classes:

state: edo:n 'to get food poisoning', awig 'to burn, get/be burned', , ilew 'to die', ečaG 'to cut oneself, get/be cut', kemar 'to get/be full', ona: 'to get/be stuck', alola 'to get/be sick', a?wat 'to get/be swollen', apyo?o 'to get/be dirty', o?či 'to be afraid', o?dastetek 'to get/be scared', ewal 'to feel lazy'

performance without control: esaw $\lambda i$ ' to slip', esal 'to vomit'

Some examples of intransitive verbs with stative marking are:

(17) ir-esaw $\lambda$ i [11NACT slip] 'I slip'

(18) ir-ilew [1 InACt die] 'I die'

(19) ir-esaw $\lambda \mathrm{i}$ [1INACT get.sick] 'I get sick'

The contrast is illustrated well in the following two verbs:

(20) ir+apyo? [1INACT be.dirty] 'I am/get dirty'

(21) $s$-apyo?Got [1ACT dirty] 'I dirty it (I make it dirty)'

While there are languages with active-inactive verb alignment in other parts of the world, languages which operate on the semantic criterion of event (for active) and non-event or stative (for inactive) seem to be found mostly only in the Chaco and adjacent areas. This feature also extends beyond the Chaco, found in several Tupí-Guaranían languages both in the Chaco and beyond. Thus, it seems to be an important feature of the Chaco, but not uniquely characteristic of only Chaco languages.

\subsubsection{Lack of verbal tense and nominal tense}

It is difficult to judge how significant it is that Matacoan, Guaicuruan, Ayoreo, and Guaraní for the most part do not mark tense on verbs - tense in these languages is either determined from context or signalled by adverbials, demonstratives, or directionals. Several have nominal tense. Nominal tense refers to instances where a nominal or part of a noun phrase (not the verb) carries the tense information for the proposition (cf. Nordlinger and Sadler 2004). In Nivaclé (Matacoan), tense is inferred from the demonstratives, as seen in (22) and (23):

(22) tsex na towak grow DEM.VIS river 'the river is rising' 
(23) tsex xa towak

grow DEM.INVIS.KNOWN river

'the river rose'

In (22) na 'visible demonstrative' correlates with a present sense - if it is visible, by inference it is present; in (23) $x a$ 'not visible but known from personal experience demonstrative' correlates typically with past sense - if you know it but cannot see it now, by inference it usually involves a past event. While Nivaclé temporal information is carried by and inferred from the demonstratives, in related Wichí, there are tense clitics, commonly attached to demonstratives and nouns (though they can also be cliticized to other constituents): - $p$ 'ante 'very remote past', -te 'distant past', -naxi 'past (more than one day)', -mati 'past (earlier that same day)', and -hila 'future'. Some examples are:

mansana ø-tolu $ø$-lile-naxi hohnat wit hi-kwes apple 3-come.from 3POss-tree-PAst ground conJunction 3-split 'the apple fell from the tree (that we saw yesterday) and split'.

(25) sinox-mati atana $ø$-yił-ti

dog-PAST now 3-die-ITERATIVE.SG

'the dog (from earlier today) is sick now'.

(Wichí examples from Terraza 2008:71-6; see Nordlinger and Sadler 2004, 2008, Tonhauser 2006, 2007, 2008 for more on nominal tense.)

More investigation is needed to determine how widespread nominal tense may be in the other Chaco languages. In any event, nominal tense is also found in several other South American languages, for example Arawakan (for example in Mawayana), Cariban, Movima, and Tupían (for example in Mundurukú, Awetí, and Tupí-Guaranían.

\subsubsection{Directional verbal affixes (affixes representing location/ direction attached to the verb)}

Chaco languages typically have a complex set of directional verbal affixes (or clitics), found for example in Matacoan, Guaicuruan, Enlhet (Maskoyan), Chamacoco (Zamucoan), and Chiriguano (Tupí-Guaranían). Some Nivaclé examples illustrating directionals are:

$\begin{array}{ll}x \text {-an-če } & \text { [1ACT-put-DIR.inside] 'I put it inside' } \\ x \text {-an-čiša?m } & \text { 'I hang it (from high toward low)' } \\ x \text {-an-ša?ne } & \text { 'I lowered it (put below)' }\end{array}$




$\begin{array}{ll}x \text {-an-šiča?m } & \text { 'I place it (from low toward high)' } \\ x \text {-an-ši? } & \text { 'I put it in (indefinite location)' } \\ x \text {-an-?akxi } & \text { 'I put it inside' } \\ x \text {-an-?ape?e } & \text { 'I put it on top' } \\ x \text {-an-?akxi } & \text { 'I put it below (inside)' } \\ x \text {-an-?e? } & \text { 'I put it in, on' }\end{array}$

Mocoví (Guaicuruan) has: n-añogot-igit he hides behind (something)' [-igit 'against']; -a?ta 'across', - awgi 'in', -ek 'outwards', -e?e 'with', -igi 'on', - $\tilde{i} i$ 'downwards', -kena 'hither', -leg 'on, over', -ñigi 'inside', -ot/-olot 'under', -o/-wo 'hither', -owgi 'inwards', -pege? 'up to', -šigim 'upwards', -weg/-eg 'out' (Grondona 1998:93).

Toba (Guaicuruan) has: -šigem 'upward', -ñi 'downward', -wek 'outward', -wo 'inward', -aGasom 'toward the water', -waq 'toward the fire'. (See Campbell 2012b for details.)

Again, this is probably a legitimate Chaco areal trait; however, it is not limited to the Chaco. Many other languages in southern South America have directional affixes or clitics on verbs. Perhaps we can set aside those with just a few directional affixes and distinguish them from the Chaco languages, which tend to have a much richer set of directionals.

\subsubsection{Other postulated areal traits in the Chaco.}

A number of other traits have been mentioned as diffused among Chaco languages. Most of these, however, are not very compelling as evidence for a Chaco linguistic area for one reason or another. Several are rather commonplace and can be found easily in languages around the world. Others are found not just in the Chaco but also widely in other areas of South America. This does not mean these traits are not diffused, but only that they provide no strong evidence for designating the Chaco as a linguistic area, since they do not distinguish Chaco languages from languages in neighboring areas that also bear these traits. In other cases, the trait in question is limited to only a few languages of the Chaco and so does not provide strong evidence of the area as a whole. In what follows, several of these shared traits which do not provide strong evidence of a linguistic area are listed. All the phonological traits that have been mentioned as possibly diffused in the Chaco are of this sort, either widely spread beyond the Chaco, or limited to only a few of the Chaco languages.

Lack of voiced stops. However, some Chaco languages do have voiced stops, e.g. some Guaicuruan languages, Vilela, and Guaranían, while numerous other South American languages also lack them, including most of the languages from the neighboring Andean zone. 
Simple vowel systems. The vowel systems of Chaco languages allegedly are simple, and indeed Enlhet (Lengua Norte) has only three vowels. However, most have more, four vowels (with length) in Guaicuruan languages, five or six vowels in Matacoan languages, and five vowels in Lule. A number of languages elsewhere in South America have simpler vowel systems for example, for example Quechuan, Aymaran, Amuesha (Arawakan), Qawasqar, Selkknam, Tehuleche, and Teushen (Chonan) have only three vowels. (See Campbell 2012b.)

Voiceless bilabial fricative $[\phi]$. Actually, only a few Chaco languages have a voiceless bilabial fricative, for example, Nivaclé and Maká; dialects of Wichí have $\phi^{w}$ alternating with $h^{w}$. This sound is rare worldwide (Maddieson 1984:226) but is found in a number of other South American languages.

Vowel nasalization. Adelaar and Muysken (2004:499) cited contrastive nasalization as a Chaco trait; however, most Chaco languages do not have contrastive nasal vowels, only Zamucoan and Tupí-Guaranían languages do. Contrastive nasalized vowels is a widespread feature elsewhere in South America.

Vowel harmony (Adelaar 2004:499; cf. Gerzenstein and Gualdieri 2003). Several Chaco languages have certain vowel alternations suggestive of vowel harmony, though it differs in form in the different languages: Maskoyan, Lule, Toba (Guaicuruan), and Chorote (Matacoan). However, most languages of the Chaco lack vowel harmony, while a number other South American languages have it (e.g. Mosetén, Chacobo, Yaminawa, etc.).

Palatalization. Messineo (2003:36) sees palatalization as "a much diffused phenomenon in all the languages of the Chaco." ${ }^{8}$ However, the kind of palatalization differs from language to language, some with a whole palatal(ized) series, some with only $k^{y}$ (Chorote, Wichí) or an alveopalatal affricate, or only with $n^{y}$ ( $\tilde{n}$, IPA $n^{j}$ or $n$ ). The palatalized sounds differ from language to language in Chaco, and are not different in terms of palatalization from many languages elsewhere in South America.

Glottalized consonants. Actually, only a few Chaco languages have glottalized consonants. Matacoan and Vilela-Lule languages have a series of glottalized (ejective) stops and affricates, and Enlhet (Maskoyan) has glottalized sonorants /m', n', n', w', y'\%.

Uvular consonants. Phonemic uvular stops (and in some, uvular fricatives) are found only in Vilela and Guaicuruan, and phonetically in Matacoan languages. Uvulars are also found elsewhere in SA, for example in several languages of the Andes.

8 "Un fenómeno muy difundido en todas las lenguas del Chaco." 
Voiceless "l". In the Chaco, voiceless "l" ([1]) is found in the Matacoan languages, Enlhet (Maskoyan), and Lule-Vilela, but is absent from many Chaco languages, and it is also found in several languages outside the area.

Simple consonant clusters (Adelaar and Muysken 2004:499). This is not a useful areal trait, since some Chaco languages have complex consonant clusters (Lule, Nivaclé, etc.), and many others elsewhere in South America have few consonant clusters and they are not complex.

Prefixing (vs. suffixing). Many Andean languages are predominantly suffixing, while several Chaco languages (but not Lule-Vilela) permit prefixes as well. However, many others also have prefixing, e.g. most Amazonian languages, languages of Tierra del Fuego, etc.

Unspecified possessor marker (affixes denoting unpossessed forms, Grondona 2003). In most languages of the Chaco, inalienably possessed nouns can bear an affix for unspecified possessor if the possessor is unknown, e.g. Nivaclé (Matacoan) wat- as in wat-aši 'someone's mouth' (compare $y$-aši 'my mouth', t-aši 'his/her/its mouth') - these nouns cannot appear with no possessive affix. While many other Chaco languages have a marker for unspecified possessor, it is found also in several other South American languages, too.

Plural object suffixes (Grondona 2003). Some Chaco languages have a specific verbal suffix to indicate plurality of the object of the verb. It is uncertain how common this is among Chaco languages.

Inclusive-exclusive contrast in First Person Plural pronominal forms. A number of Chaco languages have an inclusive-exclusive contrast in first person plural pronouns, although not all, and this is widespread also in languages elsewhere beyond the Chaco.

Polar negative adjectives. In a number of Chaco languages, there is a set of adjectives which structurally are negative versions of an adjective with the polar opposite meaning, for example Nivaclé nipitexa 'short' [ ni- NEG + pitex 'tall, long' + - $a$ NEG]; and Chiriguano (Tupí-Guaranían) ikawiã 'bad' [ikawi 'good' + -ã 'negative'] (Dietrich 1986:143). Again, this trait is true not only of Chaco languages, but is found also in a number of other South American languages. (See Campbell 2012b.)

\subsubsection{Is the Chaco a linguistic area? - conclusion}

Most diffused traits involving languages of the Chaco region are not strong indicators of a linguistic area. A few of these shared traits may seem more supportive of a Chaco Linguistic Area, but none is compelling. Most are found also in languages beyond the Chaco, and some that were thought possibly to 
be areal traits are actually characteristic of only a few of the languages within the region. Only a few of the traits seem true of a majority of languages in the Chaco, but none of these is unique to the area and some are quite commonplace in the world (for example SVO word order). The distribution of several of these traits requires more detailed investigation, particular as descriptive materials that formerly were not available for several of the languages become available. For example, the gender contrast trait is not true of all Chaco languages, and is known in many other South American languages. That the gender is not overtly marked on the nouns but is manifested in the demonstratives and adjectives which reflect the gender of the nouns they modify in several of the Chaco languages may be significant, but requires more study to see how that works both in Chaco languages and beyond. The shared genitive classifier for possessed domestic animals seems characteristic of the Chaco, though, as pointed out, a number of other South American languages also have genitive classifiers. The degree to which Chaco languages have only genitive classifiers while the genitive classifiers elsewhere form part of a larger system of classifiers in the other South American languages needs to be investigated more thoroughly. This may be a significant trait characteristic of the Chaco. A rich set of directional verbal affixes seems true of most Chaco languages, but such directionals are found in numerous other South American languages. More study is needed to determine whether the Chaco languages differ in having larger sets of directionals than others which have directional verbal affixes and how significant this might be. Demonstrative system involving a number of semantic parameters (including visible vs. not visible) also seems true of most Chaco language, but again similar demonstrative systems are also found beyond the Chaco, so the trait does not distinguish Chaco languages from others. Finally, Active-stative verb alignment does appear to be a true Chaco feature, true of most of the languages of the area, but not exclusively so. For example, the Tupí-Guaranían languages of the Chaco share this trait but Tupí-Guaranían languages far beyond the Chaco also have the trait, though they are not Chaco languages themselves.

This raises the question about whether or how a Chaco Linguistic Area might be defined. Tupí-Guaranían illustrates well the problem. TupíGuaranían shares most of these Chaco traits just listed. Since Tupí-Guaranían extends far beyond the Chaco, though with representatives also in the Chaco, its inclusion would extend the linguistic area way beyond the geographical extent of the Chaco region - hardly a "Chaco" area if defined in that way. If Tupí-Guaranían is included, since it also shares many traits with languages of the Amazonian area, how could we establish what belongs to the Chaco linguistic area and what to the Amazonian linguistic area? If Tupí-Guaranían is not included, the areal definition of the Chaco as defined on the basis of shared traits is weakened, since many of the traits seemingly reflective of the 
Chaco are also found in neighboring languages well beyond the Chaco region. This overlapping of shared traits between Chaco languages and languages beyond the Chaco complicates any attempt to define a Chaco linguistic area with neat borders.

What does this mean? The goal should be to understand the instances of diffusion cross languages. What is important is to understand the history of the languages involved - what structural features were diffused or borrowed, and how far each diffused trait extends. It is not so important to try to force the various overlapping diffused traits to fit together in coherent geographical schemes. (See Campbell 2006.) There appears to be considerable diffusion of structural traits involving Chaco languages in various ways, but these do not come together in such a way as to suggest a cohesive geographically welldefined linguistic area. Rather, they show varying linkages with languages and regions outside the Chaco on all sides, while at the same time often not linking all Chaco languages. This is not a surprising finding, since the Chaco as a cultural area is also not distinguished clearly from surrounding regions, and Chaco groups underwent cultural influences from all directions:

Culturally as well as ecologically, the Chaco is a transitional zone between the tropical plains of the Amazon Basin and the barren pampas of Argentina. Along the western border it was widely open to influences from the Andean world, and in the east it abutted on a subtropical region inhabited by Guaraní tribes ... Cultural streams from all these quarters converged in the Chaco. (Métraux 1942:210.)

In short, the varied and overlapping linguistic traits among and beyond the Chaco languages appear to parallel the distribution of the cultural traits. There were strong cultural influences from various quarters, and the linguistic traits presented here appear to mirror that - varied influences from various directions, some reaching far, others much more limited in distribution. We should not declare the existence of a Chaco linguistic area, for which the evidence is shaky at best; rather, we should just attempt to understand the language-contact induced changes, whatever their origin and distribution in the Chaco (see Campbell 2006).

\section{Conclusions}

In this paper I have looked at language contact phenomena broadly involving languages of the Chaco. I attempted to describe the situation of intensive multilingualism in the Pilcomayo region, especially in Misión La Paz. I argued that, expectations to the contrary, on-going changes here do not appear to be in the direction of convergence (greater shared structural similarity among the three languages); instead unexpected changes of divergence for found. This means that the claim that changes towards structural 
convergence in situations of intensive language contact must be re-evaluated. I argued that the often repeated claim that various Chaco languages involve language mixing was probably a misinterpretation of communication patterns involving dual-lingualism. The resistance to loanwords and reliance on native resources of the languages for terms of acculturation was described, with an attempt to explain reasons for avoidance of lexical borrowing. I speculated about the possibility that the dual-lingualism, where people understand but do not speak the other languages in this situation of intensive multilingualism, may be one factor in why words from other languages are generally not borrowed. Finally, the diffused linguistic traits among languages of the Chaco region were investigated; the answer to the question of whether the Chaco constitutes a linguistic area appears to be "no." While there are a number of shared structural traits scattered among various Chaco languages, their nature and distribution do not support establishing a Chaco linguistic area. The individual cases of diffused structural traits can be studied adequately without the assumption of a linguistic area in this region.

\section{References}

Adelaar, Willem F. H. (with Pieter C. Muysken). 2004. The languages of the Andes. Cambridge: Cambridge University Press.

Aikhenvald, Alexandra Y. 2000. Classifiers: A typology of noun categorization devices. Oxford: Oxford University Press.

Braunstein, José. 1993. Territorio e historia de los narradores matacos. Hacia una nueva carta étnica del Gran Chaco 5.4-74. Las Lomitas, Formosa: Centro del Hombre Antiguo Chaqueño.

Braunstein, José. 1996. Clasificación de las lenguas y pueblos del Gran Chaco. Lenguas indígenas de Argentina 1492-1992, ed. by Eusebia H. Martín and Andrés Pérez Diez, 19-32. (Instituto de Investigaciones Lingüísticas y Filológicas "Manuel Alvar”.) San Juan: Editorial Fundación Universidad Nacional de San Juan.

Braunstein, José and Elmer S. Miiler. 1999. Ethnohistorical introduction. Peoples of the Gran Chaco, ed. by Elmer S. Miller, 1-22. Westport, Connecticut: Bergin \& Garvey.

Brown, Cecil H. 1999. Lexical Acculturation in Native American Languages. New York: Oxford University Press.

Campbell, Lyle. 1997. American Indian languages: the historical linguistics of Native America. Oxford: Oxford University Press.

Campbell, Lyle. 2006. Areal linguistics: a closer scrutiny. Linguistic Areas: Convergence in Historical and Typological Perspective, ed. by Yaron Matras April McMahon, and Nigel Vincent, 1-31. Houndmills, Basingstoke, Hampshire: Palgrave Macmillan.

Campbell, Lyle. 2012. The classification of South American indigenous languages. The Indigenous Languages of South America: A Comprehensive Guide, ed. by Lyle Campbell and Verónica Grondona, 59-166. Berlin: Mouton de Gruyter. 
Campbell, Lyle. 2012b. Typological characteristics of South American indigenous languages. The Indigenous Languages of South America: A Comprehensive Guide, ed. by Lyle Campbell and Verónica Grondona, 259-330. Berlin: Mouton de Gruyter.

Campbell, Lyle and Verónica Grondona. 2010. Who speaks what to whom?: Multilingualism and language choice in Misión La Paz - a unique case. Language in Society 39.1-30.

Campbell, Lyle and Grondona, Verónica. 2012a. Linguistic acculturation in Nivaclé (Chulupí) and Chorote. International fournal of American Linguistics 78.335-67.

Campbell, Lyle and Verónica Grondona. 2012b. Languages of the Chaco and Southern Cone. The Indigenous Languages of South America: A Comprehensive Guide, ed. by Lyle Campbell and Verónica Grondona, 625-668. Berlin: Mouton de Gruyter.

Cardús, José. 1886. Las misiones franciscanas entre los infieles de Bolivia; descripción del estado de ellas en 1883 y 1884. Barcelona: Librería de la Inmaculada Concepción.

de Wavrin, Marquis. 1926. Les derniers Indiens primitifs du Bassin du Paraguay. Paris: Libraire Larose.

Gerzenstein, Ana and Beatriz Gualdieri. 2003. La armonía vocálica en lenguas chaqueñas de las familias Guaicurú y Mataguaya. LIAMES 3.99-112. Campinas, Unicamp.

Grondona, Verónica, and Franco Bravo. 2010. Chorote database. Unpublished.

Grondona, Verónica. 1998. Grammar of Mocoví. University of Pittsburgh Phd dissertation.

Grondona, Verónica. 2003. Are Guaycuruan and Matacoan Languages Related? A preliminary account. Paper presented at the 17th International Congress of Linguists, July 2003, Prague.

Grubb, W. Barbrooke. 1914. An unknown people in an unknown land. London: Seeley, Service \& Co.

Gumperz, John J., and Wilson, Robert. 1971. Convergence and creolization: A case from the Indo-Aryan/Dravidian border in India. Pidginization and creolization of languages, ed. by Dell Hymes, 151-167. Cambridge: Cambridge University Press.

Hermann, Walter. 1908. Die ethnographischen Ergebnisse der Deutschen PilcomayoExpedition. Zeitschrift für Ethnologie 40.120-137.

Hunt, Richard J. 1915. El choroti o yófuaha, con vocabularies lengua enimaga o towothli y chunupi o suhin. Revista del Museo de La Plata, 23 (2a serie, tomo 10). Liverpool: Henry Young \& Sons.

Karsten, Rafael. 1932. Indian tribes of the Argentine and Bolivian chaco: Ethnological studies. Helsinki: Societas Scientiarum Fennica.

Kersten, Ludwig. 1904. Die Indianerstämme des Gran Chaco bis zum Ausgange des 18. Jahrhunderts: Ein Beitrag zur historischen Ethnographie Südamerikas. Leiden: Brill.

Kirtchuk, Pablo. 1996. Lingüística areal: deixis y clasificación nominal en lenguas del Gran Chaco. Lenguas indígenas de Argentina 14921-1992, ed. by Eusebia H. 
Martín and Andrés Pérez Diez, 19-32. (Instituto de Investigaciones Lingüísticas y Filológicas "Manuel Alvar".) San Juan: Editorial Fundación Universidad Nacional de San Juan.

Klein, Harriet E. Manelis. 1993. Aculturación lingüística de los toba. Primeras jornadas de lingüística aborigen 1.185-200.

Lafone Quevedo, Samuel A. 1895. Lenguas argentinas: grupo mataco-mataguayo del Chaco, dialecto Noctén. Boletín del Instituto Geográfico Argentino 16.343-89.

Lafone Quevedo, Samuel A. 1896. Grupo mataco-mataguayo del Chaco: dialecto Vejoz. Boletín del Instituto Geográfico Argentino 17.121-176.

Lafone Quevedo, Samuel A. 1897. Introducción preliminar. Los Indios Matacos y su lengua, by Juan Pelleschi, 3-66. Boletín del Instituto Geográfico Argentino 17(1012), 18(4-6):4-248.

Lehmann-Nitsche, Robert. 1936. Die Sprachliche Stellung der Choropí (Gran Chaco). Zeitschrift für Ethnologie 69:118-24.

Lincoln, Peter C. 1979. Dual-lingualism: Passive bilingualism in action. Te Reo 22:6572.

Loutokta, Čestmír. 1968. Classification of South American Indian languages. Los Angeles: University of California, Latin American Center.

Lozano, Pedro. 1733[1941]. Descripción chorographica del Gran Chaco Gualamba. (Revised edition and prologue by Radames A. Altieri.) Tucumán: Instituto de Antropología.

Maddieson, Ian. 1984. Patterns of sounds. Cambridge: Cambridge University Press.

Martín, Herminia and José A. Braunstein. 1990-91. Nuevos rumbos de la etnolingüiística chaqueña: Geografía, historia y difusión. Hacia una Nueva Carta Étnica del Gran Chaco 2.3-12. Las Lomitas, Formosa: Centro del Hombre Antiguo Chaqueño.

Mason, J. Alden. 1950. The languages of South America. Handbook of South American Indians, ed. Julian Steward, 6:157-317. Smithsonian Institution Bureau of American Ethnology Bulletin no. 143. Washington, D.C.: Government Printing Office.

Messineo, Cristina. 2003. Lengua toba (guaycurú): aspectos gramaticales y discursivos. Munich: LINCOM.

Métraux, Alfred. 1942. Linguistic affinities of the Enimaga (Cochaboth) group. American Anthropologist 44.720-1.

Métraux, Alfred. 1946. Ethnography of the Chaco. Handbook of South American Indians, vol. 1, : The marginal tribes, ed. by Julian H. Steward, 197-370, Smithsonian Institution Bureau of American Ethnology, Bulletin 143. Washington, DC: Government Printing Office.

Miller, Elmer S. (ed.) 1999. Peoples of the Gran Chaco. Westport, Connecticut: Bergin \& Garvey.

Nadkarni, Mangesh V. 1975. Bilingualism and syntactic change in Konkani. Language 51.672-683. 
Nordenskiöld, Erland. 1912. Indianerleben: El Gran Chaco (Südamerika). Leipzig: Albert Bonnier, Merseburger. xx

Nordlinger, Rachel and Louisa Sadler. 2004. Nominal tense in crosslinguistic perspective. Language 80.776-806.

Nordlinger, Rachel and Louisa Sadler. 2008 When is a temporal marker not a tense?: Reply to Tonhauser 2007. Language 84.325-331.

Palavecino, Enrique. 1928. Las tribus aborígenes del Chaco Occidental. Anales de la Sociedad Argentina de Estudios Geográficos 3.186-209.

Pelleschi, Juan. 1897. Los indios matacos y su lengua, con una introducción por S .A. Lafone Quevedo y dos mapas. Boletin del Instituto Geográfico tomo xvii, cuadernos 10-12, and tomo xviii, cuadernos 4-6. Buenos Aires: "La Buenos Aires".

Renshaw, John (1924). Ethnographical research work during the Swedish ChacoCordillera expedition. Stockholm: C. E. Fritze.

Rodrigues, Aryon Dall'Igna and Ana Suelly Arruda Câmara Cabral. 2012. Tupían. The Indigenous Languages of South America: A Comprehensive Guide, ed. by Lyle Campbell and Verónica Grondona, 495-574. Berlin: Mouton de Gruyter.

Rona, José Pedro Rona. 1969-1972. Extensión del tipo chaqueño de lenguas. Revista de Antropología 17.20:93-103. (São Paulo.)

Rossi, Juan José. 2003. Los wichí (“mataco”). Buenos Aires: Galerna.

Seelwische, P. José. 1990. Diccionario Nivacle. (Biblioteca Paraguaya de Antropología 10.) Asunción: Centro de Estudios Antropológicos, Unviersidad Católica.

Sherzer, Joel. 1976. An areal-typological study of American Indian languages north of Mexico. Amsterdam: North-Holland.

Siffredi, Alejandra. 1973. La autoconciencia de las relaciones sociales entre los Yojwaja-chorote. Scripta Ethnologica 1.71-103.

Sušnik, Branislava J. 1978. Los aborígenes del Paraguay I: Etnología del Chaco Boreal y su periferia (siglos XVI y XVII). Asunción: Museo Etnográfico “Andrés Barbero".

Sušnik, Branislava J. 1986-1987. Los aborígenes del Paraguay, vol. 7, 1: Lenguas chaqueñas. Asunción: Mueso Andrés Barbero.

Terraza, Jimena. 2008. Gramática del wichí: fonología y morfosintaxis. Phd dissertation, Université du Québec à Montréal.

Tonhauser, Judith. 2006. The temporal semantics of noun phrases: evidence from Guaraní. Stanford University $\mathrm{PhD}$ dissertation.

Tonhauser, Judith. 2007. Nominal tense? The meaning of Guaraní nominal temporal markers. Language 83.831-869.

Tonhauser, Judith. 2008. Defining crosslinguistic categories: The case of nominal tense (Reply to Nordlinger and Sadler). Language 84.332-342.

Tovar, Antonio. 1951. Un capítulo de lingüística general: los prefijos posesivos en lenguas del Chaco, y la lucha entre préstamos morfológicos en un espacio dado. Boletín de la Academia Argentina de Letras 20.371-403. 
Tovar, Antonio. 1961. Catálogo de las lenguas de América del Sur. Buenos Aires: Editorial Sudamericana.

Tovar, Antonio. 1981. Relatos y diálogos de los matacos seguidos de una gramática de su lengua. Madrid: Ediciones Cultura Hispánica. Instituto de Cooperación Iberoamericana.

Tovar, Antonio and Consuelo Larrucea de Tovar. 1984. Catálogo de las lenguas de América del Sur. Madrid: Editorial Gredos.

Viegas Barros, José Pedro. 2002. Fonología del proto-mataguayo. Current studies on South American languages (Contributions to the 50th International Congress of Americanists), ed. by Mily Crevels, Hein van der Voort, Sérgio Meira, and Simon van de Kerke, 137-148. (Indigenous Languages of Latin America Series, 3.) Leiden: Research School CNWS of Asian, African and Amerindian Studies.

von Rosen, Eric. 1904. The Chorotes, Indians of the Bolivian Chaco. Proceedings of the International Congress of Americanists 14.649-658.

Data recebimento: 01/12/2012

Data aceite: 15/08/2013 